\title{
Suicidal destruction of Helicobacter pylori: Metabolic consequence of intracellular accumulation of ammonia
}

\author{
W D Neithercut, M A Greig, M Hossack, K E L McColl
}

\begin{abstract}
The role of $\mathrm{pH}$, citrate buffer, and urea were investigated in the suicidal destruction of Helicobacter pylori, with particular reference to the organism's urea and ammonia metabolism. The median five minute survival of $H$ pylori in the presence of $50 \mathrm{mmol} / 1$ urea in $0.2 \mathrm{M}$ citrate buffer at pH 6.0 was only $14 \%$, compared with $53 \%$ in the same solution at pH 7.0. The median amount of ammonium released into the incubating solution over five minutes was lower at pH $6.0(9 \mu \mathrm{mol})$ than at pH 7.0 (18 $\mu \mathrm{mol})$ despite similar uptake of urea. The median five minute survival of $H$ pylori in $0.2 \mathrm{M}$ citrate buffer, $\mathrm{pH} 6.0$, decreased from $89 \%$ to $14 \%$ when the urea concentration was increased from $1 \mathrm{mmol} / 1$ to $50 \mathrm{mmol} / 1$. Likewise, the recovery in the incubating solution of ammonia resulting from: the hydrolysis of urea fell from $27 \%$ to $3 \%$ when the initial urea concentration was increased from $1 \mathrm{mmol} / 1$ to $50 \mathrm{mmol} / 1$. Survival of $H$ pylori in the presence of $30 \mathrm{mmol} / 1$ urea at $\mathrm{pH} 6.0$ was compared in $0.2 \mathrm{M}$ citrate, acetate, and phosphate buffers. The median five minute survival was less in the citrate buffer, at $29 \%$, than in either the acetate buffer $80 \%$ or the phosphate buffer $100 \%$. The percentage recovery of ammonia was similar in the three buffers.

These findings indicate that the suicidal destruction of the bacterium may be explained by intracellular accumulation of ammonia due to production in excess of the rate of excretion.
\end{abstract}

Colonisation of the gastric antral mucosa by Helicobacter pylori is associated with the development of duodenal ulcers. ${ }^{12}$ Eradication of the organism from the gastric mucosa reduces the rate of relapse from $84 \%$ to $21 \%$ a year. ${ }^{3-5}$

Despite its ability to colonise the gastric mucosa, the organism does not survive well under conditions of high acidity. ${ }^{67}$ The presence of physiological concentrations of urea, however, enhances the survival of the organism at low $\mathrm{pH}^{6-8}$ It has been suggested that the production of ammonia by the organism's high urease activity may create an "alkaline microenvironment" and thereby promote its survival in acidic conditions. ${ }^{9}$
In contrast to the protective effect of urea at acidic $\mathrm{pH}$, we recently observed that the organism rapidly dies in the presence of urea in citrate buffer, $\mathrm{pH} 6 \cdot 0 .{ }^{10}$ The speed of death under these conditions suggests suicidal destruction mediated by the organism's urease activity. To investigate the biochemical basis of the suicidal process we compared the organism's urea metabolism in environments causing its rapid death with those in which it survives.

\section{Methods}

As our earlier studies had indicated that $\mathrm{pH}$, urea concentration, and type of buffer may have contributed to the suicidal process, the effect of each of these on the organism's urea metabolism and survival was examined.

1 Effect of $p H$ The survival of the organism, its urea consumption, and ammonia release in $0.2 \mathrm{M}$ citrate buffer ( $\mathrm{pH} 6.0$ ) containing $50 \mathrm{mmol} / 1$ urea were compared with those

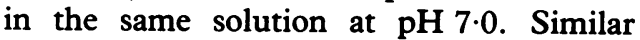
studies were also conducted with unbuffered isomolar saline at $\mathrm{pH} 6.0$ containing $50 \mathrm{mmol} / 1$ urea and $0.2 \mathrm{M}$ citrate buffer (pH 6.0) without urea.

2 Effect of urea concentration The effect of increasing initial urea concentration on urea consumption, ammonia release, and survival of the organism in $0.2 \mathrm{M}$ citrate buffer (pH 6.0) was investigated. The following urea concentrations were examined: $1 \mathrm{mmol} / 1 ; 5 \mathrm{mmol} / 1 ; 10 \mathrm{mmol} / 1$; $20 \mathrm{mmol} / \mathrm{l} ; 30 \mathrm{mmol} / 1$; and $50 \mathrm{mmol} / 1$.

3 Effect of buffer ammonium ion concentration The effect of the addition of $10 \mathrm{mmol} / 1$ ammonium chloride to $0.2 \mathrm{M}$ citrate buffer ( $\mathrm{pH} \mathrm{6.0)} \mathrm{on} \mathrm{the} \mathrm{survival} \mathrm{of} \mathrm{the} \mathrm{organism}$ was investigated.

4 Effect of type of buffer The survival of the organism in the presence of $30 \mathrm{mmol} / 1$ urea in $0.2 \mathrm{M}$ citrate buffer ( $\mathrm{pH} 6.0$ ) was compared with survival in $0.2 \mathrm{M}$ acetate buffer (pH 6.0) containing $30 \mathrm{mmol} / \mathrm{l}$ urea, and with $0.2 \mathrm{M}$ phosphate buffer (pH 6.0) also containing $30 \mathrm{mmol} / \mathrm{l}$ urea. Urea consumption and percentage ammonia release were also measured.

To start each experiment $1 \mathrm{ml}$ of a 72 hour broth culture suspension (BHI broth, $0 \cdot 25 \%$ yeast extract, and $10 \%$ horse serum) of the NCTC 11637 strain of $H$ pylori was added to $9 \mathrm{ml}$ of buffer solution containing urea, or to buffer without urea, and to isomolar saline 
Table 1 Comparison of survival and ammonium production at $p H 6.0$ and $p H 7.0$

\begin{tabular}{|c|c|c|c|}
\hline Buffer & 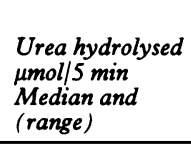 & $\begin{array}{l}\text { NH }+ \\
\text { produced } \\
\mu \text { mol/5 min } \\
\text { Median and } \\
\text { (range) }\end{array}$ & $\begin{array}{l}\% \text { Survival } \\
\text { Median and } \\
\text { (range) }\end{array}$ \\
\hline $\begin{array}{l}0.2 \mathrm{M} \text { citrate } \\
\mathrm{pH} 6.0 \\
50 \mathrm{mmol} / 1 \text { urea } \\
\mathrm{n}=8\end{array}$ & $\begin{array}{l}154 \\
(126-162)\end{array}$ & $\begin{array}{l}9 \star \\
(7-10)\end{array}$ & $\begin{array}{l}14^{\star} \\
(0-22)\end{array}$ \\
\hline $\begin{array}{l}0.2 \mathrm{M} \text { citrate } \\
\mathrm{pH} 7 \cdot 0 \\
50 \mathrm{mmol} / \mathrm{l} \text { urea } \\
\mathrm{n}=8\end{array}$ & $\left(\begin{array}{l}162 \\
(73-188)\end{array}\right.$ & $(8-21)$ & $\begin{array}{l}53 \\
(31-112)\end{array}$ \\
\hline $\begin{array}{l}\text { Isomolar saline } \\
\text { pH } 6.0 \\
50 \mathrm{mmol} / 1 \text { urea } \\
\mathrm{n}=8\end{array}$ & $\begin{array}{l}200 \\
(182-225)\end{array}$ & $\left(\begin{array}{l}10 \\
(7-12)\end{array}\right.$ & $\begin{array}{l}65 \\
(29-113)\end{array}$ \\
\hline $\begin{array}{l}0.2 \mathrm{M} \text { citrate } \\
\text { no urea pH } 6.0 \\
\mathrm{n}=8\end{array}$ & & & $\begin{array}{l}60 \\
(33-114)\end{array}$ \\
\hline
\end{tabular}

used as controls. The suspensions were incubated at $37^{\circ} \mathrm{C}$ for five minutes. Samples were collected at the start and end of the five minute incubation for bacterial culture, urea, and ammonium analyses. Each experiment was repeated to obtain a minimum of seven replicates for statistical analysis.

The method of Miles and Misra was used to establish survival of the organism in the timed samples. ${ }^{11}$ Viable colony counts were obtained on blood agar plates after six days of incubation at $37^{\circ} \mathrm{C}$ in a microaerophilic atmosphere (BBL CampyPak gas-generating system). Survival of the organism was expressed as the percentage of starting inoculum calculated from the dilution of the viable colony count in the initial broth suspension.

The $1 \mathrm{ml}$ sample collected for urea and ammonium analysis was filtered (Gelman Sciences, Acrodisc $0.2 \mu \mathrm{m}$ ) to remove the organism, snap frozen, and stored at $-20^{\circ} \mathrm{C}$ until analysis. The urea concentration was measured by the o-phthalaldehyde method using a perspective analyser (American Monitor, West Sussex). The ammonium concentration was measured following dilution in $0.2 \mathrm{M}$ phosphate buffer ( $\mathrm{pH} \mathrm{7.4)}$ by an enzymatic method (Sigma Chemical Company, Dorset), adapted for the Cobas Bio centrifugal analyser (Roche, Welwyn Garden City).

The percentage recovery of ammonia was calculated, assuming complete hydrolysis of urea removed from the incubate by the bacterium. The five minute urea concentration in the buffer was subtracted from the initial urea concentration and the result multiplied by two to give the expected final ammonia concentration. The measured concentration of ammonia was then expressed as a percentage of the expected final ammonia concentration calculated from the fall in urea concentration.

The stock buffer solutions used were $0.2 \mathrm{M}$ sodium citrate buffers ( $\mathrm{pH} \mathrm{6.0)}$ and $(\mathrm{pH} \mathrm{7.0)}$, $0.2 \mathrm{M}$ sodium acetate buffer $(\mathrm{pH} 6.0)$, and $0.2 \mathrm{M}$ sodium phosphate buffer ( $\mathrm{pH} \mathrm{6.0)}$. Isomolar sodium chloride solution was adjusted to $\mathrm{pH} 6.0$ before use. To obtain a range of urea concentrations stock solutions with urea concentrations of $0.1 \mathrm{M}, 0.5 \mathrm{M}, 1 \mathrm{M}, 2 \mathrm{M}$,
$3 \mathrm{M}$ and $5 \mathrm{M}$ were made. All the stock solutions were stored at $-20^{\circ} \mathrm{C}$ until use. To set the initial urea concentration in the buffer $100 \mu \mathrm{l}$ of the appropriate stock urea solution was added to $8.9 \mathrm{ml}$ of the required buffer to give urea concentrations of $1 \mathrm{mmol} / 1,5 \mathrm{mmol} /$ $1, \quad 10 \mathrm{mmol} / 1, \quad 20 \mathrm{mmol} / 1, \quad 30 \mathrm{mmol} / 1$, or $50 \mathrm{mmol} / \mathrm{l}$ in the final suspension. Buffers were equilibrated at $37^{\circ} \mathrm{C}$ and their $\mathrm{pH}$ checked before each experiment.

All reagents used were analar grade. The statistical method used to analyse the data was the Mann-Whitney U test.

\section{Results}

EFFECT OF pH

The median five minute survival of $H$ pylori, when incubated at $37^{\circ} \mathrm{C}$ in $0.2 \mathrm{M}$ sodium citrate buffer ( $\mathrm{pH} \mathrm{6.0)}$ with an initial urea concentration of $50 \mathrm{mmol} / 1$ was only $14 \%$ (range 0-22\%) compared with 53\% (range 31$112 \%$ ) when incubated in the same solution but at $\mathrm{pH} 7.0(\mathrm{p}<0.01)$ (fig 1$)$. The survival of the organism in citrate buffer at $\mathrm{pH} 6.0$ with $50 \mathrm{mmol} / \mathrm{l}$ urea was also reduced in comparison with survival in isomolar saline containing $50 \mathrm{mmol} / 1$ urea (median $65 \%$, range $29-113 \%$ ) $(\mathrm{p}<0.01)$ and with survival in $0.2 \mathrm{M}$ sodium citrate buffer ( $\mathrm{pH} 6.0$ ) without any added urea (median 60\%, range 33-114\%) ( $p<0.01$ ) (fig 1).

Urea utilisation was similar in pH 6.0 buffer and in $\mathrm{pH} 7.0 \mathrm{buffer}$, being $154 \mu \mathrm{mol} /$ five minutes $(126-162 \mu \mathrm{mol})$ and $162 \mu \mathrm{mol} /$ five minutes (73-188 $\mu \mathrm{mol}$ ), respectively (table 1 ). The median five minute amount of ammonium found in the incubate at $\mathrm{pH} 7.0$ was $18 \mu \mathrm{mol}$, however (range 8-21 $\mu \mathrm{mol}$ ), which was significantly greater than at $\mathrm{pH} 6.0(9 \mu \mathrm{mol})$ (range $7-10 \mu \mathrm{mol})(\mathrm{p}<0.01)($ table 1$)$.

\section{EFFECT OF UREA CONCENTRATION}

The median five minute survival of the organism in $0.2 \mathrm{M}$ citrate buffer ( $\mathrm{pH} 6.0$ ) progressively fell with increasing initial urea concentrations from $89 \%$ (range $19-124 \%$ ) at 1 $\mathrm{mmol} / \mathrm{l}$ to $39 \%$ (range $13-87 \%$ ) at $10 \mathrm{mmol} / \mathrm{l}$,

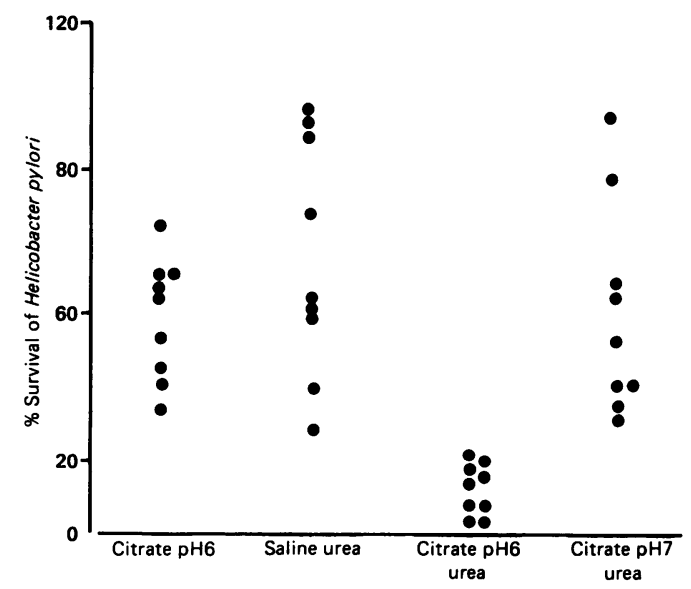

Figure 1 Percentage survival of H pylori NCTC 11637 at the end of a five minute incubation $(n=9)$, using $0.2 \mathrm{M}$ citrate buffer ( $p H$ 6.0), isomolar saline containing $50 \mathrm{mmol} / \mathrm{l}$ urea, $0 \cdot 2 \mathrm{M}$ citrate buffer ( $\mathrm{pH}$ 6.0) containing $50 \mathrm{mmol} / \mathrm{l}$ urea, and $0.2 \mathrm{M}$ citrate buffer ( $p H \mathrm{H} \cdot 0$ ) containing $50 \mathrm{mmol} / \mathrm{l}$ urea. 
Figure 2 Amount of urea used by $H$ pylori during the five minute incubation in $0 \cdot 2 \mathrm{M}$ citrate buffer (pH 6.0) containing from 1 to $50 \mathrm{mmol} / \mathrm{l}$. Urea concentrations of 1 to $20 \mathrm{mmol} l \mathrm{l}(\mathrm{n}=7)$, $30 \mathrm{mmol} / \mathrm{l}(n=17)$ $50 \mathrm{mmol} / \mathrm{l}(\mathrm{n}=9)$. initial urea concentrations

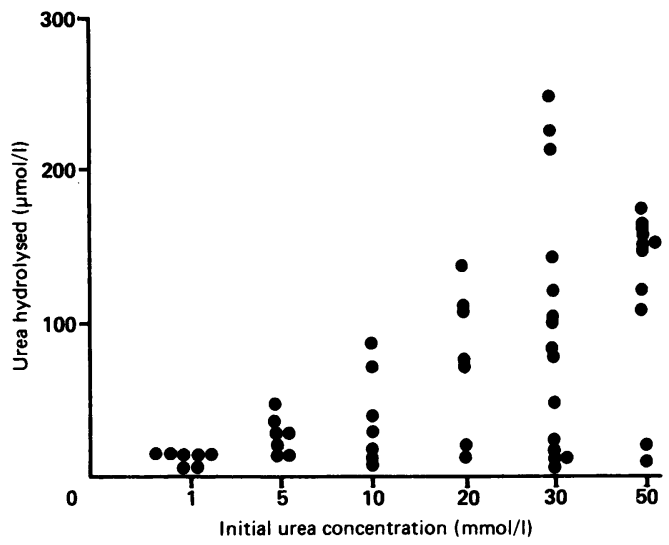

$29 \%$ (range $10-64 \%$ ) at $30 \mathrm{mmol} / 1$ and to $9 \%$ (range $0-22 \%$ ) at $50 \mathrm{mmol} / \mathrm{l}$. Although the median percentage survival of the organism fell as the initial urea concentration increased, the amount of urea used by the organism during the five minute incubation increased from $9 \mu \mathrm{mol}$ (range $7-9 \mu \mathrm{mol}$ ) at an initial urea concentration of $1 \mathrm{mmol} / 1$ to $32 \mu \mathrm{mol}$ (range $14-92 \mu \mathrm{mol}$ ) at $10 \mathrm{mmol} / 1$ (p $<0.05), 98 \mu \mathrm{mol}$ (range 15-281 $\mu \mathrm{mol}$ ) at $30 \mathrm{mmol} / 1(\mathrm{p}<0.01)$, and $146 \mu \mathrm{mol}$ (range $11-171 \mu \mathrm{mol}$ ) at an initial urea concentration of $50 \mathrm{mmol} / \mathrm{l}(\mathrm{p}<0.01)$ (fig 2). The percentage recovery of ammonia from the hydrolysis of urea fell as the initial urea concentration increased (fig 3 ). With an initial urea concentration of $1 \mathrm{mmol} / \mathrm{l}$, the median five minute recovery of ammonia was $27 \%$ (range 7-94\%) compared with $18 \%$ (range 15-80\%) at $10 \mathrm{mmol} / 1,16 \%$ (range $4-315 \%$ ) at $30 \mathrm{mmol} / 1$, and only $3 \%(2-22 \%$ ) at $50 \mathrm{mmol} / 1$ urea ( $p<0.01$ compared with $1 \mathrm{mmol} / 1 \mathrm{urea})$.

\section{EFFECT OF BUFFER AMMONIUM ION}

CONCENTRATION

The survival of the organism in $0.2 \mathrm{M}$ citrate buffer ( $\mathrm{pH} 6.0)$ in the presence of $10 \mathrm{mmol} / 1$ ammonium chloride was investigated. The median ammonium concentration of the 12 replicate experiments when measured at the start was $10.7 \mathrm{mmol} / \mathrm{l}$ (range 9.7-13.1 $\mathrm{mmol} / \mathrm{l}$ ) and at the end it was $10.9 \mathrm{mmol} / \mathrm{l}$ (range 10.6 $11.3 \mathrm{mmol} / \mathrm{l})$. The five minute survival of the organism in buffer with ammonium chloride (median $64 \%$, range $20-137 \%$ ) was similar to its survival in $0.2 \mathrm{M}$ sodium citrate buffer (pH 6.0), without any additions (median $60 \%$, range $33-148 \%$ ).

\section{EFFECT OF TYPE OF BUFFER}

The median five minute survival in buffer

Figure 3 Recovery of ammonia, expressed as a percentage of the amount of ammonia expected to have been formed as a result of hydrolysis of urea by $\mathrm{H}$ pylori in $0.2 \mathrm{M}$ citrate buffer ( $p H$ 6.0) with initial urea concentrations from 1 to $50 \mathrm{mmol} / \mathrm{l}$. Urea concentrations of 1 to $20 \mathrm{mmolll}(n=7)$, $30 \mathrm{mmol} / \mathrm{l}(\mathrm{n}=17)$, and $50 \mathrm{mmol} / \mathrm{l}(\mathrm{n}=9)$.

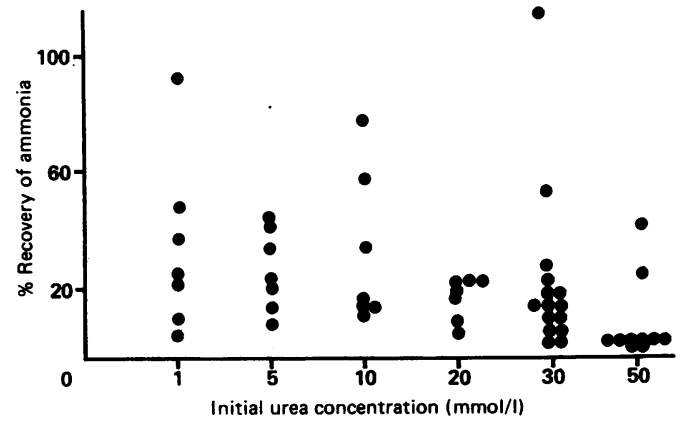

pH 6.0 in the presence of $30 \mathrm{mmol} / 1$ urea when citrate buffer was used was $29 \%$ (range 10 $64 \%$ ) compared with $80 \%$ (range 26-160\%) when acetate buffer was used ( $p<0.01$ ) (table 2 ). The amount of urea used by the organism in the acetate buffer (median $215 \mu \mathrm{mol}$, range 18$272 \mu \mathrm{mol}$ ) was not significantly different from that in the citrate buffer (median $97 \mu \mathrm{mol}$, range 5-282 $\mu \mathrm{mol}$ ). The median five minute ammonium release was similar in the acetate buffer (33 $\mu \mathrm{mol}$, range $7-132 \mu \mathrm{mol}$ ) to that in the citrate buffer ( $19 \mu \mathrm{mol}$, range $7-41 \mu \mathrm{mol})$. The percentage of ammonia recovered from the hydrolysis of urea in the acetate buffer $(12 \cdot 1 \%)$ was also similar to that $(8.6 \%)$ in the citrate buffer. In the absence of urea the five minute survival in citrate buffer ( $\mathrm{pH} \mathrm{6.0)}$ was still reduced $(68 \%$, range $33-163 \%)$ when compared with survival in the acetate buffer at pH $6.0(95 \%$, range $36-211 \%)(\mathrm{p}<0.05)$.

The median five minute survival of $H$ pylori in the presence of $30 \mathrm{mmol} / \mathrm{l}$ urea in phosphate buffer at $\mathrm{pH} 6.0(100 \%$, range $72-128 \%)$ was also greater than that in citrate buffer $(42 \%$, range $27-55 \%)(p<0.05)$ (table 3$)$. In the absence of urea survival was similar in citrate (83\%, range $75-103 \%)$ and phosphate buffers $(90 \%$, range $82-126 \%)$. A similar amount of urea was consumed in the phosphate buffer (83 $\mu \mathrm{mol}$, range $0-296 \mu \mathrm{mol}$ ) and in the citrate buffer $(120 \mu \mathrm{mol}$, range $19-264 \mu \mathrm{mol})$. The median percentage recovery of ammonia from urea hydrolysed was again similar for both buffers, $17 \%$ for citrate and $15 \%$ for phosphate (table 3).

\section{Discussion}

It has been proposed that the ammonia produced by the urease activity of $H$ pylori generates an alkaline microenvironment to allow the organism to survive in the acid gastric environment. ${ }^{9}$ It was therefore of interest to discover that incubating the organism in citrate buffer at $\mathrm{pH} 6.0$ in the presence of a high urea concentration resulted in its rapid suicidal destruction. We have previously observed this with all strains of the bacterium tested. ${ }^{10}$

The importance of the hydrogen ion concentration of the buffer in the suicidal process was shown by improved survival in citrate buffer solution ( $\mathrm{pH} \mathrm{7.0)}$ ) with $50 \mathrm{mmol} / \mathrm{l}$ urea compared with that in the same solution at $\mathrm{pH} 6 \cdot 0$. Although the organism consumed similar

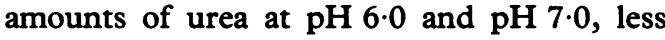
ammonia was released into the incubate at pH 6.0. This reduced excretion of ammonia at pH 6.0 may explain the organism's impaired survival at this $\mathrm{pH}$ in the presence of urea.

The survival of $H$ pylori decreased with increasing initial urea concentration in the pH 6.0 citrate buffer, indicating that the suicidal destruction was linked to urease activity. This observation was consistent with our previous finding that the addition of the urease inhibitor hydroxyurea enhanced the survival of the organism in citrate buffer at $\mathrm{pH} 6 \cdot 0 .{ }^{10}$ The percentage recovery of ammonia following hydrolysis of urea fell with increasing initial urea concentration, indicating that the 
Table 2 Comparison of survival and ammonium production in citrate buffer and acetate buffer

\begin{tabular}{|c|c|c|c|c|}
\hline Buffer & $\begin{array}{l}\text { Urea } \\
\text { hydrolysed } \\
\text { umol/5 min } \\
\text { Median and } \\
\text { (range) }\end{array}$ & $\begin{array}{l}\mathrm{NH}_{4}^{+} \\
\text {produced } \\
\text { umol/5 min } \\
\text { Median and } \\
\text { (range) }\end{array}$ & $\begin{array}{l}\% \text { Recovery } \\
\text { of } \mathrm{NH}_{4}+ \\
\text { Median and } \\
\text { (range) }\end{array}$ & $\begin{array}{l}\% \text { Survival } \\
\text { Median and } \\
\text { (range) }\end{array}$ \\
\hline $\begin{array}{l}0.2 \mathrm{M} \text { citrate buffer } \\
\text { pH } 6.0 \text { with } 30 \mathrm{mmol} / 1 \text { urea } \\
\mathrm{n}=18\end{array}$ & $(\stackrel{97}{5-282})$ & $(7-41)$ & $\begin{array}{l}8 \cdot 6 \% \\
(2 \cdot 6-61)\end{array}$ & $\begin{array}{l}29^{\star} \\
(15-64)\end{array}$ \\
\hline $\begin{array}{l}0.2 \mathrm{M} \text { acetate buffer } \\
\mathrm{pH} 6.0 \text { with } 30 \mathrm{mmol} / 1 \text { urea } \\
\mathrm{n}=18\end{array}$ & $\begin{array}{l}215 \\
(18-272)\end{array}$ & $\left(\begin{array}{l}33 \\
(7-132)\end{array}\right.$ & $\begin{array}{l}12 \cdot 1 \% \\
(3 \cdot 5-90)\end{array}$ & $\begin{array}{l}95 \\
(36-211)\end{array}$ \\
\hline
\end{tabular}

${ }^{\star} \mathrm{p}<0.01$.

organism may have been unable to excrete the ammonia generated by urea hydrolysis as rapidly as it was produced. This failure to excrete ammonia may explain its rapid death.

Our studies have shown that citrate was essential for the suicidal process to occur. $H$ pylori survived in phosphate and acetate buffers at $\mathrm{pH} 6.0$ with concentrations of urea which caused suicidal destruction in citrate buffer. The percentage recovery of ammonium from the urea consumed during incubation in these buffers, however, was similar to that in citrate buffer. The contribution of citrate to the suicidal process, therefore, cannot be explained by changes in urease activity or ammonia excretion.

Localisation of the organism's urease activity by means of urease linked precipitation of silver followed by visualisation of the precipitate by electron microsopy had suggested that urease activity was associated with the periplasmic membrane of the organism..$^{12}$ In our experiments less ammonia was recovered from the incubate than calculated from urea consumed and ammonium ions added to the incubation medium were not taken up by the organism. This indicates that the urease activity of $H$ pylori is either located within the cell or that it is closely associated with the cell membrane, taking up extracellular urea and releasing ammonia within the cell.

Ammonium produced by urease activity may be used in the formation of glutamate and glutamine by glutamate dehydrogenase and glutamine synthetase, respectively. Both of these reactions consume high energy intermediates, but glutamate dehydrogenase also uses $\alpha$ ketoglutarate in the formation of glutamate. Although citrate is used in the formation of $\alpha$ ketoglutarate, when present in high concentrations it may act as a competitive inhibitor of isocitrate dehydrogenase. ${ }^{13}$ The activity of this enzyme is required for the formation of $\alpha$ ketoglutarate from citrate. The simultaneous inhibition of synthesis and stimulation of utilisation of $\alpha$ ketoglutarate could result in the complete depletion of this compound in the bacterium. This would result in intracellular accumulation of ammonia and impairment of energy production.

$H$ pylori may need an active transport process to excrete excess ammonia produced by urease activity. Impairment of energy production would also impede this and would therefore tend to increase intracellular accumulation of ammonia. Through these mechanisms citrate, urease activity, and $\mathrm{pH}$ could combine to produce a rapid catastrophic accumulation of ammonia within the organism resulting in its death.

$H$ pylori is difficult to eradicate with conventional treatment. Even triple treatment with tri-potassium dicitratobismuthate, metronidazole, plus either amoxycillin or tetracycline for two to four weeks fails to eradicate the infection in $10 \%$ of patients. ${ }^{1}$ The development of antibiotic resistance is also proving a problem. ${ }^{14}$ Our in vitro observations may indicate a potential new approach to killing the organism in vivo. We have previously shown that infusion of solutions containing urea using a nasogastric tube can stimulate ammonia production by the organism ${ }^{15}$ thereby raising the possibility that the in vitro conditions required for eradication of the organism may be reproduced in the human stomach.

In conclusion, $H$ pylori rapidly dies in citrate buffer ( $\mathrm{pH} \mathrm{6.0)}$ containing urea. This may be explained by the metabolic consequences of rapid intracellular accumulation of ammonia.

Table 3 Comparison of survival and ammonium production in citrate buffer and phosphate buffer

\begin{tabular}{|c|c|c|c|c|}
\hline Buffer & $\begin{array}{l}\text { Urea } \\
\text { hydrolysed } \\
\text { Hmol/5 min } \\
\text { Median and } \\
\text { (range) }\end{array}$ & $\begin{array}{l}\mathrm{NH}_{1}+ \\
\text { produced } \\
\mu m o l / 5 \text { min } \\
\text { Median and } \\
\text { (range) }\end{array}$ & $\begin{array}{l}\% \text { Recovery } \\
\text { of } \mathrm{NH}_{4}+ \\
\text { Median and } \\
\text { (range) }\end{array}$ & $\begin{array}{l}\% \text { Survival } \\
\text { Median and } \\
\text { (range) }\end{array}$ \\
\hline $\begin{array}{l}0.2 \mathrm{M} \text { citrate buffer } \\
\mathrm{pH} 6.0 \text { with } 30 \mathrm{mmol} / 1 \text { urea } \\
\mathrm{n}=7\end{array}$ & $(120)$ & $\begin{array}{c}39 \\
(32-41)\end{array}$ & $\begin{array}{l}17 \% \\
(7 \cdot 4-21)\end{array}$ & $\left(\begin{array}{l}42^{\star} \\
27-55)\end{array}\right.$ \\
\hline $\begin{array}{l}0.2 \mathrm{M} \text { phosphate buffer } \\
\text { pH } 6.0 \text { with } 30 \mathrm{mmol} / 1 \text { urea } \\
\mathrm{n}=7\end{array}$ & $(\stackrel{83}{0-296)}$ & $\stackrel{30}{(5-36)}$ & $\left(\begin{array}{l}15 \% \\
(4 \cdot 3-19 \%)\end{array}\right.$ & $\left(\begin{array}{l}100 \\
(72-127)\end{array}\right.$ \\
\hline
\end{tabular}

${ }^{\star} p<0.05$. 
1 Goodwin CS, Armstrong JA, Marshall BJ. Campylobacter pyloridis. gastritis and peptic ulceration. J Clin Pathol 1986;39:353-65.

2 Maddocks EC. Helicobacter pylori (formerly Campylobacter pyloridis/pylori) 1986-1989: A review. J Clin Pathol 1990;43:353-6.

3 Marshall BJ, Goodwin CS, Warren JR, et al. Prospective double-blind trial of duodenal ulcer relapse after eradication of Campylobacter pylori. Lancet 1988;ii:1438-42.

4 Rauws EAJ, Tytgat GNJ. Cure of duodenal ulcer associated with eradication of Helicobacter pylori. Lancet 1990; with eradic

5 Oderda G, Forni M, Dell'Ollo D, Ansaldi N. Cure of peptic ulcer associated with eradication of Helicobacter pylori. Lancet 1990; i:1599.

6 Marshall BJ, Barrett LJ, Prakesh C, McCallum RW, Guerrant RL. 1987 Protection of Campylobacter pyloridis but not Campylobacter jejuni against acid susceptibility by urea. In: Kaijser B, Falsen E, eds. Campylobacter IV: Proceedings of the Fourth International Workshop on Campylobacter Infection. Goteborg, 1987. University of Goteborg: Goteborg, 1987:402-3.

7 Tompkins DS, West AP. Campylobacter pylor, acid, and bile. J Clin Pathol 1987;40:1387.

8 Marshall BJ, Barrett LJ, Prakash C, McCallum RW,
Guerrant RL. Urea protects Helicobacter (Campylobacter) pylori from the bactericidal effect of acid. Gastroenterol 1990;99:697-702

9 Brady CE, Hadfield JL, Hyatt JR, Utts SJ. Campylobacter pyloridis-survival in a hostile environment. Am J Gastroenterol 1986;81:855.

10 Greig MA, Neithercut WD, Hossack M, McColl KEL. Harnessing of urease activity of Helicobacter pylori to induce self destruction of the bacterium. J Clin Pathol 1991;44:157-9.

11 Miles AA, Misra SS. The estimation of the bactericidal power of the blood. $J$ Hyg 1938;38:732-48.

12 Bode $G$, Malfertheiner $P$, Nilius $M$, Ditschuneit $H$. Ulstrastructural localisation of urease in outer membrane and structural localisation of urease in outer membrane and periplasm of

13 Larner J. Intermediary metabolism and its regulation. New Jersey: Prentice-Hall, 1971.

4 Glupczynski Y, Birette A, Koster ED, et al. Metronidazole resistance in Helicobacter pylori. Lancet 1990;i:976-7.

15 Chittajallu RS, Neithercut WD, Macdonald AMI, McColl KEL. The effect of increasing Helicobacter pylori ammonia production by urea infusion on plasma gastrin concentrations. Gut 1991;32:21-4. 